\title{
$\mathrm{Na}_{2} \mathrm{SO}_{4}$ 水溶液中の鉄に対するア之ノ安息香酸類の 腐食抑制作用*
}

\author{
小林 賢三**, 清水 健一**, 伏見 英樹***, 秋丸 裕司** \\ ** 慶応義塾大学理工学部化学科 \\ *** (現) 富士通株式会社
}

\section{Inhibitive Effects of Aminobenzoic Acids on Corrosion of Iron in Aerated Sodium Sulphate Aqueous Solution}

\author{
Kenzo Kobayashi, Ken-ichi Shimizu, Hideki Fushimi \\ and Hiroshi Akimaru* \\ **Faculty of Science and Technology, Keio University \\ ***Fujitsu Limited
}

\begin{abstract}
Inhibition effects of $o_{-}, m-$, and $\mathrm{p}$-aminobenzoic acids and benzoic acid on iron corrosion have been studied in aerated $0.5 \mathrm{M}$ sodium sulphate aqueous solution at $40^{\circ} \mathrm{C}$ by potentiodynamic polarization mesurements. o-Aminobenzoic acid gave the best corrosion inhibition among the inhlbitors tested in the aqueous solutions with $\mathrm{pH}$ values between 5 and 8 , The inhibition efficiency increased with increasing molar concentration of o-aminobenzoic acid in the aqueous solution, The corrosion potentials shifted largely toward noble direction with an increase in its concentration, because of inhibiting strongly the anodic iron dissolution reaction. A pale green precipitate film was observed to be produced on the surface while the iron specimen was dipped in the aqueous solution with $o$-aminobenzoic acid. The film thickness was found to depend on the corrosion rates and to become thinner with an decrease in corrosion rate. No visible film could be observed on the surface at 0.5 molar concentration of $o$-aminobenzoic acid given maximum inhibition, but the surface had been kept strong water repellent property. The precipitate film was found to be a chelate compound consisted of a ferric ion and two molecules of $o$-aminobenzoic acid by IR and UV spectroanalysis. It was concluded that iron corrosion was inhibited mainly by chemisorption film donated both amino and carboxyl radicals of $o$-aminobenzoic acid to iron surface, just as a surface chelate, and sec ondarily by chelate compound film produced on the surface.
\end{abstract}

\section{1. 緒言}

酸素が溶けている中性付近の低濃度塩水溶液中の鉄に 対し安息香酸ナトリウムが，優れた腐食抑制効果を示す ことが知られており ${ }^{1)}$ ，また実用にも供せられている。 しかし, 安息香酸ナトリウムは, 腐食環境中の溶存酸素 量 $^{2}$, 溶解しているアニオンの種類とその濃度 ${ }^{3}$, 及び 溶液の $\mathrm{pH}^{4)}$ によって，腐食抑制効果が影響を受ける。

\footnotetext{
* '84, '85 春期学術講演大会で発表

** 干223 横浜市港北区日吉 3-14-1 (3-14-1, Hiyoshi, Kohoku-ku, Yokohama, 223 Japan)

*** 厂511-01 三重県桑名郡多度町御衣野 1500 (Tadomati, Kawana, Mie Pref. 511-01 Japan)
}

安息香酸イオンの防食作用は, 主として鉄のアノード溶 解反応を強く抑制し，腐食電位を大きく貴側に移行させ る結果，溶存酸素が鉄の不働態化に対して有利に作用す るためであるとされている5゙。したがって，脱気環境下 や腐食性アニオンが多量に存在する環境など，鉄を不働 態化することが困難な環境では, 安息香酸イオンは腐食 抑制効果を示さない。

本研究は, 安息香酸イオンの防食性能を向上させる目 的で, 安息香酸のベンゼン環に吸着性のあるアミノ基を オルソ $(o-)$, メタ $(m-)$, パラ $(p-)$ 位に導入したアミノ 安息香酸類の鉄に対する腐食抑制効果を, 安息香酸イオ 
ンによる鉄の不働態化が困難とされる $0.5 \mathrm{M} \mathrm{Na}_{2} \mathrm{SO}_{4}$ 水溶液中で回転電極を用いた動電位分極法により検討し た。

\section{2. 実験方法}

試薬特級安息香酸, $o-, m-$, 及び $p-$ アミノ安息香酸 を再結晶法により精製したものをインヒビターとして用 いた。鉄試料は Johnson Matthey Co. 製純鉄棒 (5 $\mathrm{mm} \phi)$ をテフロン樹脂に埋め込み，その断面を電極表 面とした。電極表面は No. 2000 までのエメリー紙で研 磨した後, 超音波アセトン浴で 10 分間脱脂を行った。 次いで $3 \mathrm{~N} \mathrm{HCl}$ 中で 2 分間エッチングを行った後, 蒸 留水で十分に洗浄し, 実験に供した。腐食液としては特 級 $\mathrm{Na}_{2} \mathrm{SO}_{4}$ を再蒸留水に溶かし $0.5 \mathrm{M}$ 溶液としたもの を用いた。溶液の $\mathrm{pH}$ は希 $\mathrm{H}_{2} \mathrm{SO}_{4}$, 及び希 $\mathrm{NaOH}$ 水 溶液で調整し，なお，溶液の $\mathrm{SO}_{4}{ }^{2-}$ 濃度が変化しない よう留意した。分極曲線の測定は, 北斗電工社製回転電 極装置 (HA 101), 東方技研社製ポテンショスタット (2020)，ファンクションゼネレター（2230）を用いた。 電極電位はルギン毛細管を介し，飽和カロメル電極 (SCE) に照合し，対極に Pt 網を用いた。実験は $0.5 \mathrm{M}$ $\mathrm{Na}_{2} \mathrm{SO}_{4}$ を $50 \pm 1^{\circ} \mathrm{C}$ に保ち，その中に電極を浸漬して 比較的電位が安定した約 50 分後, 自然浸漬電位から $2 \times 10^{-2} \mathrm{~V} / \mathrm{sec}$ の速度でカソード分極曲線を求めた。一 たん，自然浸漬状態に戻した後，同様な方法でアノード 分極曲線を求めた。また，本研究では，電極の回転数 を $1000 \mathrm{rpm}$ とした。

また，鉄表面の赤外線反射スペクトルの測定には電子 材料用純鉄 $(\mathrm{C}: 0.007 \% ， 50 \times 15 \times 0.8 \mathrm{~mm})$ を用いた。 試験片の表面処理は No. 2000 までのエメリ一紙で研磨 し，次いで，超音波四塩化炭素浴で 10 分間脱脂後，片 面の $30 \times 10 \mathrm{~mm}$ を残してエナィル塗装を行った。塗装 が完全に乾燥固化した後，眽酸-過塩素酸溶液中で，30 秒間，定電流 $\left(700 \mathrm{~mA} / \mathrm{cm}^{2}\right)$ で電解研磨を行い，その 後エタノール，蒸留水で十分に洗浄し実験に供した。鉄 試験片を $0.5 \mathrm{M} O$-アミノ安息香酸を含む $0.5 \mathrm{M} \mathrm{Na}_{2} \mathrm{SO}_{4}$ 水溶液 (大気開放) 中に所定時間浸漬後, 試験片を取り 出し, 蒸留水で良く洗浄, 乾燥した。日本分光社製赤外 分光計 $(102 \mathrm{~A})$ により反射角 $60^{\circ}$ で鉄試験片表面に生 成した皮膜の赤外スペクトルの測定を行った。

\section{3. 実験結果及び考察}

\section{1 アミノ安息香酸類の防食効果}

$0.5 \mathrm{M} \mathrm{Na}_{2} \mathrm{SO}_{4}$ 水溶液 $\left(50^{\circ} \mathrm{C}\right.$ ，大気開放， $\left.\mathrm{pH}=6\right)$ 中 に $o-, m-$, 及び $p-$ アミノ安息香酸をそれぞれ添加し， 鉄の分極曲線に与える影響を調べた結果を Fig. 1 3 に示した。図から明らかなようにいずれのアミノ安息香

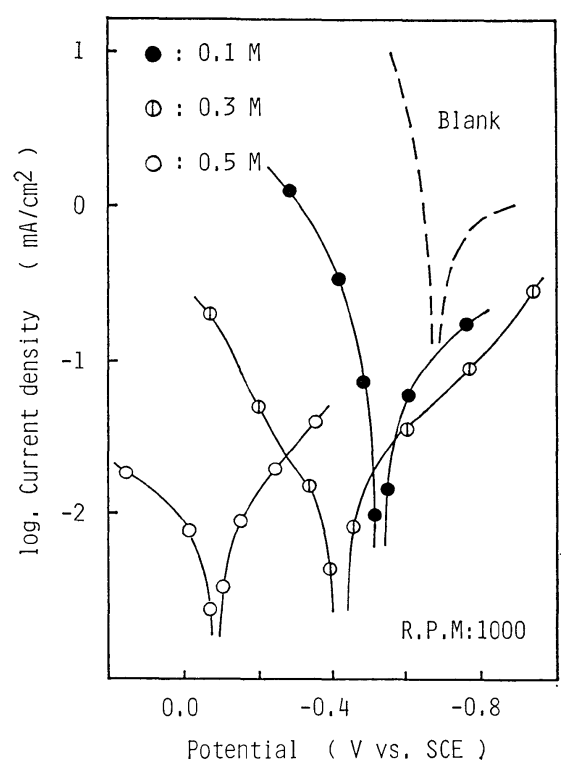

Fig. 1 Effects of concentration of $o$-aminobenzoic acid on the polarization curves of iron in aerated $0.5 \mathrm{M} \mathrm{Na}_{2} \mathrm{SO}_{4}$ at $50^{\circ} \mathrm{C}$.

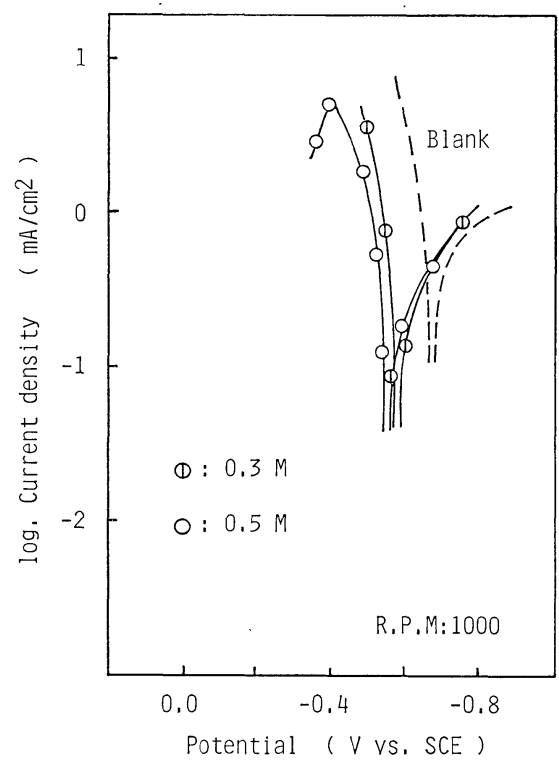

Fig. 2 Effects of concentration of $m$-aminobenzoic acid on the polarization curves of iron in aerated $0.5 \mathrm{M} \mathrm{Na}_{2} \mathrm{SO}_{4}$ at $50^{\circ} \mathrm{C}$.

酸も鉄のアノード反応を抑制することが分かる。しか し， $m$-, 及び $p-$ アミノ安息香酸 (Fig. 2, 及び Fig. 3) は鉄のアノード反応を抑制するが，カソード反応に影響 を及ぼさないために，鉄の腐食が酸素拡散支配であるこ の腐食環境では，ほとんど腐食抑制効果を与えない。そ れに対して，o-アミノ安息香酸（Fig. 1) は，アノード 反応と同時にカソード反応をも抑制していることがわか 


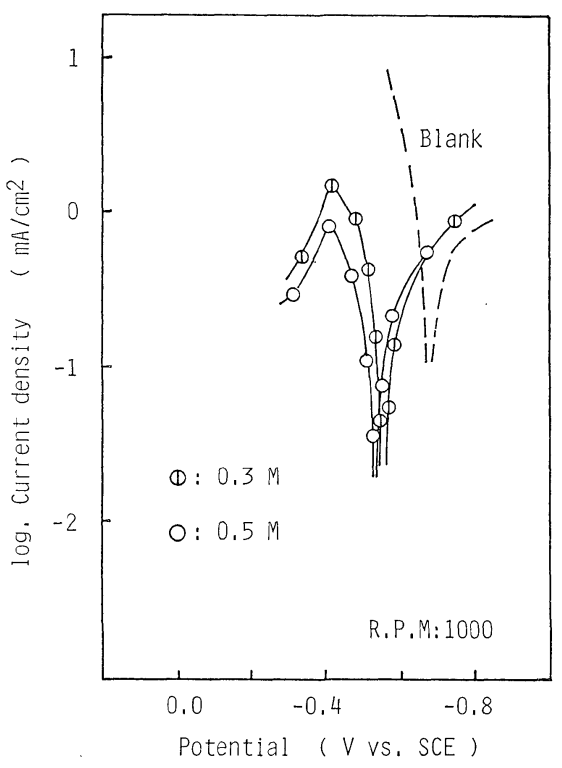

Fig. 3 Effects of concentration of $p$-aminobenzoic acid on the polarization curves of iron in aerated $0.5 \mathrm{M} \mathrm{Na}_{2} \mathrm{SO}_{4}$ at $50^{\circ} \mathrm{C}$.

る。また前二者と異なり， 0 -アミノ安息香酸はその添加 濃度が $0.5 \mathrm{M}$ の時, 腐食電位を $-0.08 \mathrm{~V}$ vs. SCE ま で大きく貴側に移行し，また腐食電流密度を $0.008 \mathrm{~mA} /$ $\mathrm{cm}^{2}$ まで減少させ，非常に優れた防食性を示すことがわ かる。また，アノード分極を行った後, 電極表面を観察 すると， 0 -アミノ安息香酸を用いた場合，電極表面は疎 水性を示す淡緑色の薄い皮膜で覆われていた。アノード 分極時に，電極表面上に蹯水性の淡緑色皮膜の形成は， 安息香酸, $m$ - 及び $p$-アミノ安息香酸では認められない 現象であった。

o-アミノ安息香酸はその構造から見て, アミノ基とカ ルボキシル基が隣接しているので，アノード反応で溶出 する鉄（II）イオンや鉄（III）イオンと反応してキレー 卜化合物を形成する可能性がある。Dinsel ら ${ }^{6)}$ は，o-ア ミ/安息香酸は $\mathrm{pH}=4.5$ の水溶液中で, 鉄（II）イオ ン，及び鉄（III）イオンと不溶性の安定なキレート化合 物を形成することを報告している。したがって，Fig. 1 に示した $\mathrm{pH}=6$ の環境で，鉄電極表面に生成した淡緑 色皮膜はアミノ安息香酸の鉄塩ではなく, 0 -アミノ安息 香酸と鉄（II）イオン，あるいは鉄（III）イオンのキレ 一下化合物と考光られるが，沈殿皮膜中の鉄イオンの定 性分析の結果, 鉄（II）イオンが認められないことか ら，鉄（III）イオンとのキレート化合物であると断定し た。また，この生成する淡緑色の皮膜の厚さは腐食電流 密度と関係し, 腐食電流密度が高い程厚い皮膜が観察さ れた。添加濃度の高い $0.5 \mathrm{M}$ の場合，生成する皮膜が 目に見觉ない程薄いにも拘らず，腐食電流密度を著しく
低下させている。このことはキレート化合物の皮膜のみ による作用だけでなく，キレート化合物に至らないまで も，アミノ基とカルボキシル基の双方の強い吸着が鉄表 面に起こって，腐食抑制作用に寄与していると考兄られ る。この吸着皮膜の腐食抑制作用への寄与は，鉄の不働 態化剤としてのみ働く安息香酸をインヒビターとしたと きの分極曲線の結果と比較することにより明らかにされ る。

$\mathrm{pH}=7.5$ の安息香酸を含む $0.5 \mathrm{M} \mathrm{Na}_{2} \mathrm{SO}_{4}$ 水溶液中 の鉄の分極曲線に与兄る安息香酸添加濃度の影響を Fig. 4 に示した。図から明らかなように安息香酸は鉄 のアノード反応を抑制するが，カソード反応に殆ど影響 を及ぼさないことがわかる。添加濃度を $0.4 \mathrm{M}$ 以上と したとき，腐食電位が急に大きく貴側に移行し，アノー ド電流密度が著しく小さくなり，鉄が不働態化されたこ とを示す。これに対し $o$-アミノ安息香酸は Fig. 1 亿見 られるように， $0.5 \mathrm{M}$ の添加で，腐食電位を安息香酸 の場合之同様，貴側に大きく移行させるが，アノード分 極曲線は安息香酸の場合と異なり, ターフェル領域が認 められる。腐食電位 $-0.08 \mathrm{~V}$ vs SCE は鉄を不働態化 させるに十分な電位であることから， $o$-アミノ安息香酸 も安息香酸同様に不働態化剂として働いていると考兄ら れるが，ターフェル領域が認められることから，o-アミ ノ安息香酸のアミノ基とカルボキシルアニオンによる強 い吸着（表面キレートなど）が鉄表面に起こっているこ とを示唆していると考光られる。

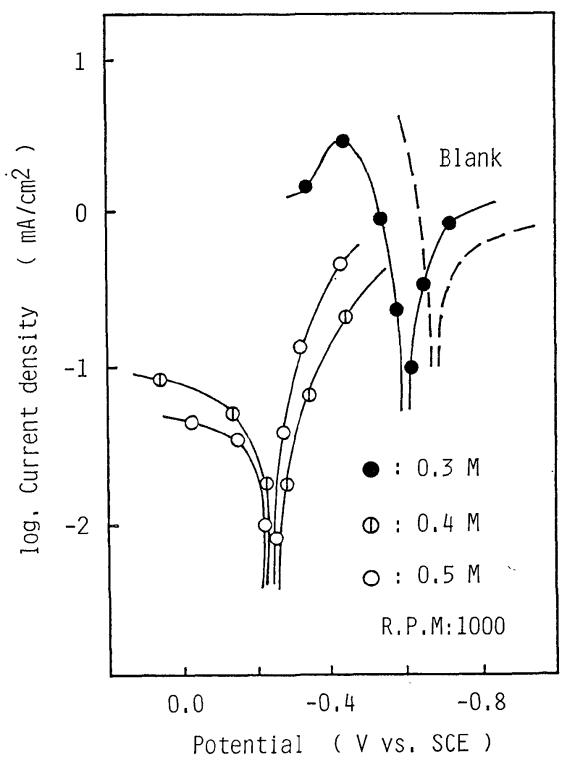

Fig. 4 Effects of concentration of benzoic acid on the polarization curves of iron in aerated $0.5 \mathrm{M} \mathrm{Na}_{2} \mathrm{SO}_{4}$ at $50^{\circ} \mathrm{C}$. 


\subsection{0 -アミノ安息香酸の腐食電流密度に及ほす $\mathrm{pH}$ の影響}

上記のように, $\mathrm{pH}=6$ の $0.5 \mathrm{M} \mathrm{Na}_{2} \mathrm{SO}_{4}$ 水溶液中に おける $o$-アミノ安息香酸による腐食抑制作用が，鉄イ オンと $o$-アミノ安息香酸とのキレート化合物の沈殿皮 膜, および表面キレート皮膜などによるものであれば, 水溶液の水素イオン濃度の影響を受けるものと考兄られ る。そこで $0.5 \mathrm{M} o$-アミノ安息香酸を含む $0.5 \mathrm{M}$ $\mathrm{Na}_{2} \mathrm{SO}_{4}$ 水溶液の $\mathrm{pH}$ がアノード，及びカソード分極曲 線の外挿法により求めた腐食電流密度に与える影響を調 べ，それらの間の関係を Fig. 5 亿示した。な抏，眓中 にインヒビター無添加時, 及び $0.5 \mathrm{M}$ 安息香酸を添加 した場合の結果も併せて示した。

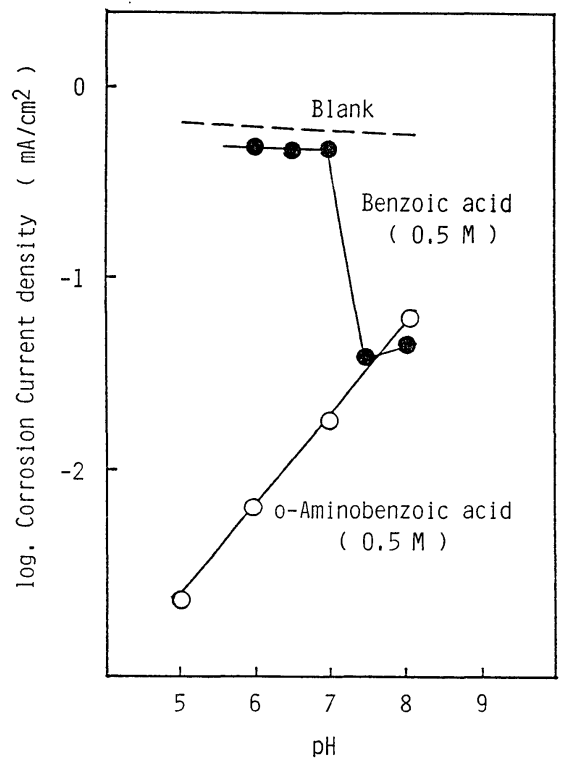

Fig. 5 Relation between the corrosion current density and $\mathrm{pH}$ value in the aqueous solution.

酸素拡散支配型の鉄の腐食は, 従来から良く知られて いることであるが，図に示されたよらに $\mathrm{pH}$ が 5 から 8 の範囲では汪とんど変化しない。また，安息香酸は $\mathrm{pH}$ が 7.5 付近の非常に狭い範囲 で, 腐食電流密度を低下 させ，それ以下の低い $\mathrm{pH}$ では防食作用を示さないこと がわかる。これに対し， $o$-アミノ安息香酸は, 試験し た $\mathrm{pH}$ が 5 から 8 の間の水溶液中での鉄の腐食電流密度 を低下させ，pH 值が小さくなる程，腐食電流密度を著 しく低下させる傾向を示していることがわかる。また， アノード分極曲線測定後の鉄表面観察の結果，試験した 溶液の $\mathrm{pH}$ 值 (5-8) では，いずれ子鉄表面は踈水性の 淡緑色の皮膜で覆われていた。また，腐食電流密度が大 きい程，その表面に形成される皮膜は厚くなり，その皮
膜下では局部腐食が起こっていることが認められた。こ のことは, 溶液の $\mathrm{pH}$ が大きくなるに従って, 鉄表面に 均一で安定なキレート吸着皮膜が形成され難いことを示 し, 鉄表面で形成される皮膜の安定性が溶液の $\mathrm{pH}$ に影 響されるるのと考光られる。

\section{3 沈殿皮膜組成と構造}

$o$-アミノ安息香酸は鉄表面にち密な淡緑色の皮膜を形 成することによって, $0.5 \mathrm{M} \mathrm{Na}_{2} \mathrm{SO}_{4}$ 水溶液中の鉄を防 食することが知られた。そこで，この防食性皮膜の組成 と構造を赤外線反射スペクトル法などで検討した。

$0.5 \mathrm{M} o$-アミノ安息香酸を含む $0.5 \mathrm{M} \mathrm{Na}_{2} \mathrm{SO}_{4}$ 水溶 液 (大気開放, $\mathrm{pH}=5,50^{\circ} \mathrm{C}$ ) 中に鉄試験片を 45 分間 浸漬した。浸漬後蒸留水で十分に洗浄し, 次いで乾燥し た。その試験片表面の赤外線反射スペクトルを Fig. 6 (B) に示した。図中に比較のために $o$-アミノ安息香酸 の $\mathrm{KBr}$ 法による赤外線吸収スペクトル $(\mathrm{A})$ ，及び鉄試 験片に皮膜を形成させたと同条件の水溶液に，鉄（III) イオンを添加し，生成した沈殿物の $\mathrm{KBr}$ 法による赤外 線吸収スペクトル $(\mathrm{C})$ を示した。四から明らかなよう に，鉄試験片表面に生成した皮膜（B）と鉄（III）イオ ンと 0 -アミノ安息香酸との反応で生成した沈殿物（C) の赤外線吸収スペクトルが類似し，o-アミノ安息香酸 (A) のそれと異なることが分かる。すなわち（A）の $3000 \mathrm{~cm}^{-1}$ 付近の $\mathrm{OH}$ 伸縮振動々 $1600 \mathrm{~cm}^{-1}$ 付近の $\mathrm{C}=0$ 伸縮振動飞帰属される吸収が，(B) と（C) に 認められない。(A) 飞認められる $3480 \mathrm{~cm}^{-1}$ と 3380 $\mathrm{cm}^{-1}$ の $\mathrm{NH}_{2}$ 伸縮振動が，(B) と (C) では, それぞ れ $3300 \mathrm{~cm}^{-1}$ と $2900 \mathrm{~cm}^{-1}$ に移行している。また，

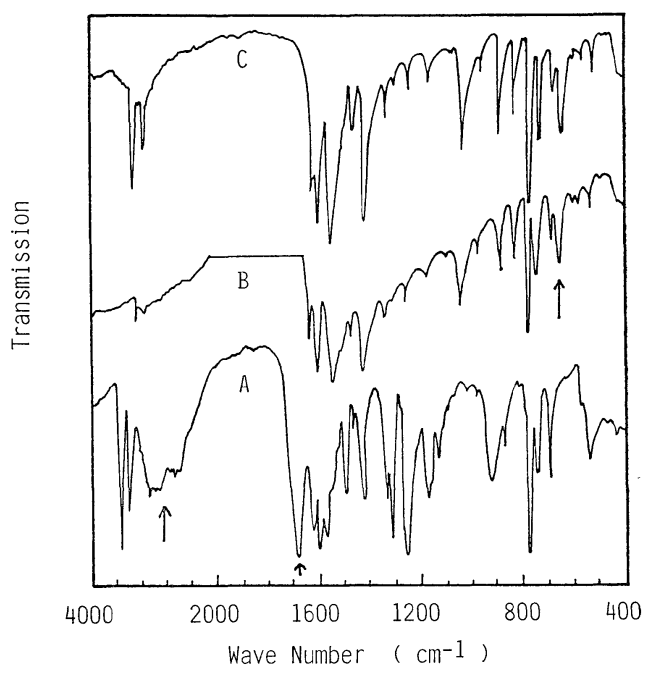

Fig. 6 Infrared spectra of $o$-aminobenzoic acid (A), the precipitate on the surface during corrosion test (B), and the reaction product of ferric ion and $o$-aminobenzoic acid (C). 
（A）に認められない $1580 \mathrm{~cm}^{-1}$ と $630 \mathrm{~cm}^{-1} に$ に 新た な吸収スペクトルが (B)，(C) に現れている。前者の 吸収はカルボキシレートに帰属され7), : 後者は金属と $\mathrm{N}$ 原子との間の配位結合による ものと考えられる。した がって, 鉄表面に形成される淡緑色の皮膜は，水溶液中 で 0 -アミノ安息香酸と鉄（III）イオンとの反応で得ら れた沈殿物と同じ構造を有したキレート化合物であると 推定される。

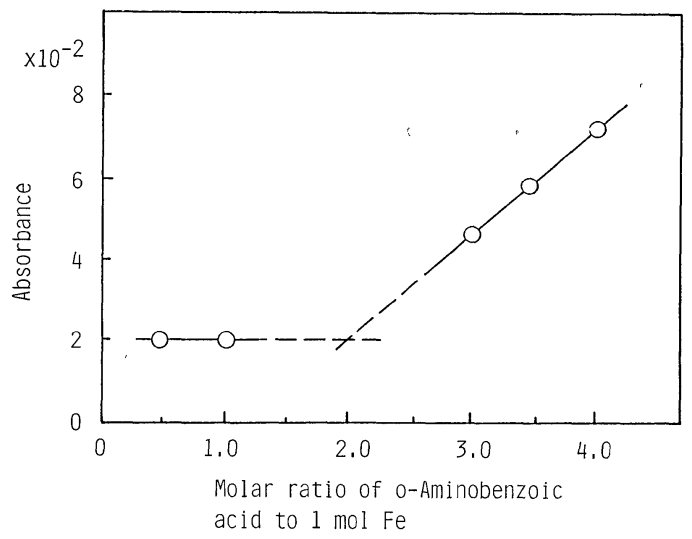

Fig. 7 Relation between absorbance at $320 \mathrm{~nm}$ and molar ratio of $o$-aminobenzoic acid to ferric ion in the aqueous solution.

次に, 鉄 (III) イオンと 0 -アミノ安息香酸のキレー 卜化合物が最も得られやすい環境 $(\mathrm{pH}=4)$ を選び，そ の水溶液中の鉄 (III) イオンに対する 0 イミノ安息香酸 の濃度を変化させ，その水溶液の $320 \mathrm{~nm}$ に打学 外線吸収スペクトルの吸光度を測定した。その結果を Fig. 7 に示した。 $320 \mathrm{~nm}$ の紫外線吸収スペクトルは $o$-アミノ安息香酸のカルボキシル基の $n-\pi^{*}$ 遷移に基 づくものである ので，反応する鉄（III）イオンより oーアミノ安息香酸濃度が不足した状態では, キレート化 合物の解離による一定の吸光度を示すが，o-アミノ安息 香酸濃度が過剰になると, その量に対応して吸光度は直 線的に増加する。したがって，これら二つの直線の交点 が鉄 (III) イオンと 0 -アミノ安息香酸の結合比になると 考えられる。すなわち, これらの結合比は, 図に示した ように，一つの鉄 (III) イオンに対し，二分子の $o-ア ミ$ ノ安息香酸が結合したキレート化合物であると推定でき る。また合成したキレート化合物中の鉄（III）イオンの 定量分析から， $15.6 \%$ の鉄（III）イオンが含まれてい ることが分かった。この值は Fig. 7 から得た結果から 予測される化合物中の鉄（III）イオン含量より少ないこ とを示す。更に，一つの鉄（III）イオンに対し二分子の oーアミノ安息香酸が配位したキレート化合物の構造を考 えると，この化合物は電荷を持つことになる。一般に不
溶性のキレート化合物はその電荷が零でなければならな い。したがって，本実験環境下に沶いても， Dinsel ら が示した構造（I）を有したキレート化合物が生成した と考光ると，鉄（III）イオンの含有率は $15.3 \%$ とな り，分析值と良い一致を示す。<smiles></smiles>

( I )

以上の結果から，鉄試験片表面に生成する沈殿皮膜は （I）に示した構造と考えられる。o-アミノ安息香酸を 含む水溶液中に，鉄（III）イオンを添加と同時に沈殿が 生じることから，このキレート化合物の生成速度は非常 に速いものと考学られる。したがって，溶液中に十分な 量の 0 -アミノ安息香酸が存在すると, 鉄から溶出した 鉄イオンは直ちにキレート化され，鉄表面に沈殿し，防 食効果に寄与したものと考觉られる。しかしながら，鉄 試験片表面での皮膜成長は鉄の溶解速度と関係し，腐食 電流密度が高い程厚くなり，その皮膜は水道水などの流 水では脱離しないが，脱脂綿などでこすると，その大部 分が脱離することから, 密着性, 及びち密性に優れてい るとはいえない。また， $O$ アアミノ安息香酸の添加量が高 い場合には，薄い皮膜でありながら，高い防食効果を示 すことなどから，o-アミノ安息香酸が示す高い防食性は 鉄表面に生成した沈殿皮膜それ自体だけによるとは考え 難く, O-アミノ安息香酸の鉄表面へのカルボキシルアニ オンとアミノ基の吸着による表面キレート皮膜，それに 続いてキレート化合物の沈殿皮膜，及び不働態皮膜の複 合した結果であると考学るのが妥当であろう。

\section{4. 結 論}

$0.5 \mathrm{M} \mathrm{Na}_{2} \mathrm{SO}_{4}$ 水溶液 (大気開放, $50^{\circ} \mathrm{C}$ ) 中の鉄 腐 食に対して， $o-, m-$, 及び $p$-アミノ安息香酸の防食性を 検討した結果， 0 -アミノ安息香酸が鉄のアノード及びカ ソード反応を強く抑制し，最も優れた防食性を示した。 その腐食抑制作用は，ベンゼン環に隣接して存在するカ ルボキシル基とアミノ基の双方を鉄表面に提供した表面 キレート吸着皮膜の生成, 及び（I）に示した構造を有 するキレート化合物の沈殿皮膜の生成であると推論され る。このように，o-アミノ安息香酸が表面キレート，及 びキレート沈殿皮膜を形成することにより，鉄の腐食を 抑制することは，溶存酸素のない，あるいは塩化物イオ ンなどの腐食性アニオンを含む環境中に和いても，十分 な防食効果を示すことが期待される。これらに関し次に 
報告したいと考えている。

(Received August 25, 1985)

\section{文献}

1）例总ば，I. N. Putilova et al.: “Metallic Corrosion Inhibitors", p. 151, Pergamon Press (1960).

2) Q. T. M. Slaiman \& D. E. Davies: Proc. of 3rd European Symposium on Corrosion Inhibitors, p. 739 (1970).

3) D. M. Brasher \& A. D. Mercer: Brit. Corros. $J ., 3,120$ (1968).

4) D. E. Davies \& Q. J. M. Sláiman: Corros. Sci.
11, 671 (1971).

5) D. E. Davies \& Q. J. M. Slaiman: Corros. Sci., 11, 683 (1971).

6) D. L. Dinsel \& T. R. Sweet: Anal. Chem., 35, [13] 2077 (1963).

7) 例党ば, C. N. R., Rao: “Chemical Application of Infrared Spectroscopy”, p. 199, Academic Press (1963).

8) 例えば, K. Nakamoto: "Infrared Spectra of Inorganic and Coordination Compounds", p. 146, John wiley (1963).

9）例衤ば，荒木 峻ほか：“有機化合物のスペクト ル飞よる同定法”第 4 版, p. 281 , 東京化学同人 (1983). 